\title{
STUDY REGARDING ENZYMATIC CHARACTERISTICS ON THE FLOUR
}

\author{
Maria Popa ${ }^{1}$ \\ Roxana Bostan ${ }^{2}$
}

\begin{abstract}
Falling time of cereals and their products is an index of the enzyme alfa amylase activity, which in correctly ripen and collected under dry conditions grains occurs in negligible amounts. However under unfavourable atmospheric conditions the moisture level of cereals is higher than $15 \%$ the enzyme becomes activated. In consequence it causes dramatic damage to starch kernels. Dough prepared from such flour has unfavourable physico-chemical properties not granting good quality bread baking. Therefore knowledge of the degree of impairment of cereals and their products allows their correct qualification and the following way of their use, for instance: for feeding purposes, for making mixtures, that is impaired cereals with those not damaged by alfa amylase or working out individual technological processes with „improvers" to avoid unexpected losses.
\end{abstract}

Key words: enzyme, alfa amylase, flour, falling time

JEL code: $Q 10$

\section{Introduction}

The supply of the population with quality food products is difficult to happen in when pollution is greatly present. The global development of food industry and service networks has caused some incidents with global characteristic focused on food safety. These problems implied withdrawing food products and important consequences on consumer health as well.

Romanian food product industry tends to align to the requirements of modern production necessary in the exploitation of methods and modern technologies in order to eliminate the risk of food contamination.

The policies of the European Union and of the World Health Organization are focused on food security as the responsibility of the food sector operator, ensured throughout the food chain beginning with the primary production "farm-to-fork".

Through a systemic approach of the food chain, it is possible to avoid product contamination. Therefore, it is essential that raw materials meet quality requirements, that the hygiene of staff, facilities, machines and equipments is appropriate. The result is reflected in the quality and the safety of the finished product.

From the food products perspective, three types of activities have appeared which contribute to the good organisation of the food processes:

- agricultural production

- food production

- network of food services

The hygienic quality of foods is achieved by a series of rules:

- $\quad$ no physical, chemical, biochemical and microbiological deterioration

- no micro-organisms, additives, foreign substances over the limits allowed by standards and laws.

\footnotetext{
1 “1 Decembrie 1918” University, Faculty of Sciences, 510009 - Nicolae Iorga Street 11-13, Alba Iulia, Romania, mariapopa2010@yahoo.com

2 “1 Decembrie 1918” University, Faculty of Sciences, 510009 - Nicolae Iorga Street 11-13, Alba Iulia, Romania.
} 
- no infestation with insects and parasites

- no loss of the nutritional quality and psycho sensorial proprieties by mentioned degradation

The knowledge of the food raw materials quality allows the obtaining of higher quality food products, applying an appropriate technology.

Despite having a system of quality monitoring and surveillance of food products, their contamination may occur by contaminants that are introduced naturally or accidentally or through the improper handling of food. Contamination of food products with microbiological agents, chemicals and physical or food allergens remains a key challenge for public health.

Contamination is the change in the normal composition of the food due to the presence of foreign components in action and their concentration can affect the health of consumers. The change of psycho, physical, chemical or biological properties of food products throughout the food chain can occur through contamination with various pollutants.

To ensure health security, food wholesomeness and maintaining control of the content of different contaminants, sanitation rules on consumer goods must be respected under specific legislation in all EU countries.

Enzymes are used for a long time to convert complex carbohydrates in fermentation processes. Except for sugar processing and use of this glucozoizomerazei glucozil cyclodextrin transferase, enzymes are used for carbohydrate hydrolytic type. Reducing the size of macromolecules is the main transformation suffered. In fact, the progress made in understanding and modeling Enzymology allows all biochemical transformations. Hydrolysates amylolitic enzymes are able to degrade specific glycosidic linkages of starch and its degradation products up to stage oligoglucide. Participate in numerous biological processes such as maturation and germination of cereals, starchy substrates by digestion by animals and microorganisms. They are, on the other hand, appreciated in industry where their ability to depolymerised starch is the major technological transformations such as preparation of glucose syrup or bread. The objective is to transform bakery flour, plus possibly other ingredients (yeast, salt, malt, milk fat) in food preparation and easily preserved by operation of alcoholic fermentation and baking. Alcoholic fermentation is a clear step to understand the role of amylase. In general, biochemical processes are catalyzed by enzymes. It is estimated that the most important biochemical processes and proteolysis are amiloliza.

Amiloliza is the process of hydrolysis of starch under the action of $\alpha$ and $\beta$ amylase. The process is particularly important in dough of flour because its sugars are insufficient to maintain throughout the fermentation to technological bakery process. Bread obtained only from the fermentation of carbohydrates own flour has a low volume, is dense and undeveloped. Maltose derived from starch hydrolysis is the main sugar that is fermented and thus provides the necessary amount of gas in the final part of the technological process. For this reason, the starch is considered as the main source of carbohydrates fermentescibile of dough. In a normal bakery is $6 \ldots 12 \%$ hydrolysed starch in dough. Amylases allow the production of glucose and maltose, which are then fermented, a poor fermentation, resulting in an increase of less than bread. Low percentage of carbohydrates in the flour initial content (0.5 to $2 \%)$ involved a hydrolysis of starch in the proportion of $1-2 \%$. Action amylases the dough is influenced by environmental conditions: the degree of hydration of the dough, temperature and state of degradation of starch granules. Baking dough cause a gradual increase in internal temperature up to $100^{\circ} \mathrm{C}$ with dual action on enzymatic activity and physical state of starch. However, the surface temperature will be about $250^{\circ} \mathrm{C}$. During temperature increase, there is a short period or longer (depending on how baking) in which enzymes can act. Amylase is activated by adding water to the dough during the manufacturing.

Dough fermentation and, especially, the production of carbon dioxide are related to the presence of these carbohydrates fermentescibile. The $\alpha$-amylase activity has a significant effect on excessive water absorption capacity of the dough and the core training. An excessive activity causes 
an overproduction of dextrin's, which leads to a colours core with large pores, and a colourful crust.

The ratio of $\alpha$ and $\beta$ amylase activity influence the quality of bread. If there is an excess of $\alpha$-amylase against $\beta$-amylase, it can not all dextrin hydrolysis formed and this leads to the formation of a sticky dough.

\section{Research methodology}

The determination principle consists in gelatinization of flour suspension in a test-tube located in a boiling water bath and measurement of gel liquefaction degree under the influence of amylase. The falling time of grain and its products is the activity criterion of alpha-amylase enzyme which occurs in small quantities in grain when they are correctly grown and gathered in dry conditions. In conditions of increased cereal moisture, above $15 \%$, especially when crops are gathered in unfavourable weather conditions, activation of alpha-amylase occurs, which results in starch damage. Dough made of such flour has disadvantageous physicochemical properties which negatively influence the quality of bread. Therefore, the determination of the damage degree of grain and their products allows classifying and using cereals differently, for example:

- $\quad$ as feed

- $\quad$ in mixtures of damaged cereal and grain not affected by alpha-amylase

- development of individual technological processes with addition of "improvers" to avoid unexpected losses

Equipment

- $\quad$ Technical balance with 0.01 g accuracy

- $\quad$ Reaction tube with rubber stopper

- $\quad$ Burette with distilled water $(25 \mathrm{ml})$ or measuring glass $(25 \mathrm{ml})$

- $\quad$ Mechanical shaker

- $\quad$ Viscometer stirrer

- $\quad$ Protective holder for tube with stirrer

Method

Tube washing system

- $\quad$ Weigh of $7 \mathrm{~g}$ of flour on a tarred laboratory spoon.

- $\quad$ Immerse the flour sample in $25 \mathrm{ml}$ of distilled water.

- After closing the tube with rubber stopper stirs the sample with water on an automatic shaker for $10 \mathrm{sec}$. or by hand 20 times up and down.

Put the stirrer in the tube (attempting to collect all the flour remaining on the stopper) pushing the sample part still on the tube's wall down with the stirrer.

Put the tube with the stirrer in the protective holder and transfer it to automatic instrument heated earlier to $100^{\circ} \mathrm{C}$ (filled up exclusively with distilled water).

- Immediately after that block the tube with the latch, move left the mixing countershaft, which will start the mixing after 5 seconds.

Automatic mixing stops after 60 seconds allowing the pusher to go down by itself in the time depending on the amount of enzymes.

The falling time is recorded on the reader, what is signalled at the time of finishing the analysis.

Write down the recorded falling time seen on the digital display or check it on the attached printer. flours.

Compare the result with norms and/or the Table with the data indicating the usefulness of 


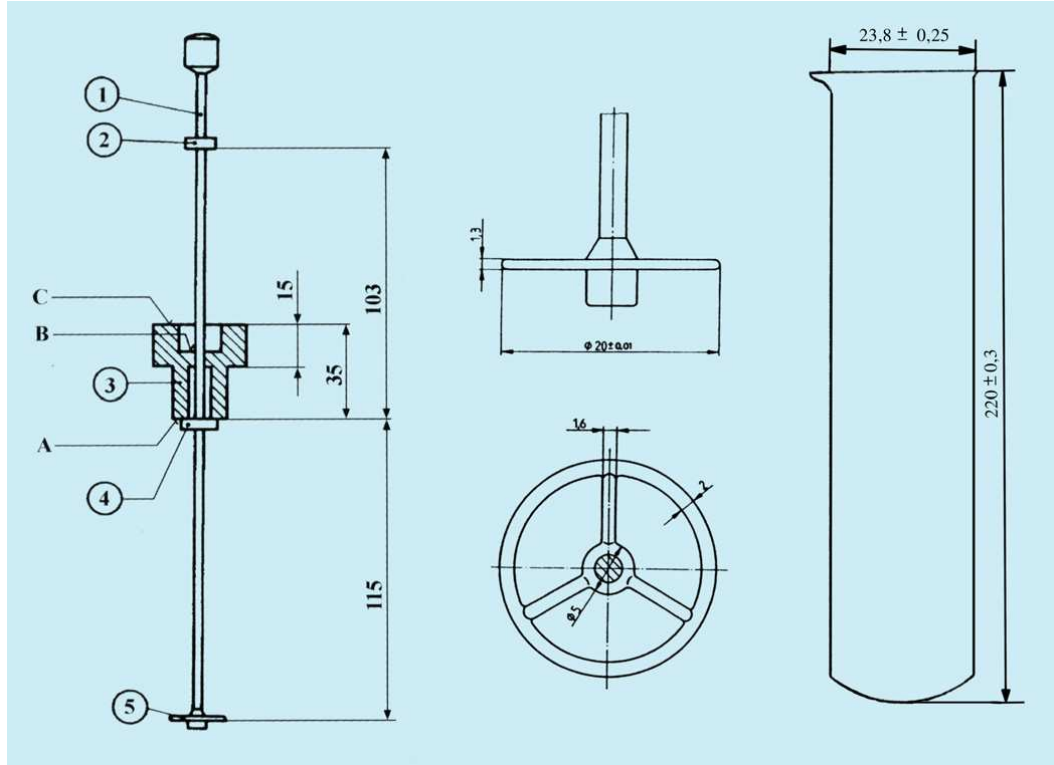

Fig. no. 1. Schematic diagram of viscometric stirrer

Source: Instruction manual. Automatic instrument for assaying of amylolytic enzymes activity according to Sadkiewicz - Hagberg method

(a) wheel diagram, (b) glass viscometric tube, (c) 1 - stirrer rod, 2 - upper stirrer limiter (5) internal o21 $\pm 0.08 \mathrm{~mm}, 3$ - stopper, 4 - bottom stirrer limiter external o23.8 $\pm 0.25 \mathrm{~mm}, 5$ - disc-pusher $220 \pm 0.3 \mathrm{~mm}$ long

Table no. 1

Table of interpretation of results on falling time according to ZBPP

\begin{tabular}{|c|c|c|c|c|}
\hline \multirow{3}{*}{ Grup } & \multirow{2}{*}{\multicolumn{2}{|c|}{$\frac{\text { Falling time }}{\text { flour }}$}} & \multirow{3}{*}{ Conclusion } & \multirow{3}{*}{ Technological recommendations } \\
\hline & & & & \\
\hline & wheat one & rye one & & \\
\hline 1 & below80 s & $\begin{array}{l}\text { below } \\
70 \mathrm{~s}\end{array}$ & $\begin{array}{l}\text { very high activity of } \\
\text { alfa-amylase in flour }\end{array}$ & $\begin{array}{l}\text { Flour is not suitable for direct baking. In small quantities it } \\
\text { can be mixed with group } 4 \text {. }\end{array}$ \\
\hline 2 & $90-150 \mathrm{~s}$ & $75-100 s$ & $\begin{array}{c}\text { high activity of alfa- } \\
\text { amylase }\end{array}$ & It is suitable for preparation of mixtures with group 4. \\
\hline 3 & $170200 \mathrm{~s}$ & $\begin{array}{c}125-200 \\
\mathrm{~s}\end{array}$ & $\begin{array}{c}\text { medium activity of } \\
\text { alfa-amylase }\end{array}$ & Suitable for baking. \\
\hline 4 & Above $300 \mathrm{~s}$ & $\begin{array}{c}\text { Abow } 250 \\
\mathrm{~s}\end{array}$ & $\begin{array}{c}\text { low activity of alfa- } \\
\text { amylase }\end{array}$ & $\begin{array}{l}\text { Rye fluor is not suitable for direct bread baking with high } \\
\text { acidity level. It should be used for wheat and rye products or } \\
\text { mixtures with group } 2 \text { or } 1 \text {. Wheat flour should be mixed } \\
\text { with group } 2 \text { or } 1 \text {. } \\
\text { In exceptional cases it can be used for pastry with large } \\
\text { quantities of sugar. }\end{array}$ \\
\hline 5 & $60-750 s$ & $60-400 \mathrm{~s}$ & $\begin{array}{c}\text { value variations are } \\
\text { found }\end{array}$ & \\
\hline
\end{tabular}

The solution protected by patent. It is adapted to international requirements according to PN-ISO 3093 standard 


\section{Results}

Samples analyzed were purchased from different localities in the region of Transylvania. For each sample ten determinations were made of the index falls. The average value of determination is placed in the table below.

Table no. 2

The results of the index falls analyses of the flour samples

\begin{tabular}{|c|c|c|c|}
\hline Sample & $\begin{array}{l}\text { Determination } \\
\text { value } \\
\quad \text { Ic (sec) } \\
\end{array}$ & $\begin{array}{l}\text { Normal } \\
\text { value } \\
\text { Ic }(\text { sec) } \\
\end{array}$ & Observations \\
\hline 1- Gambas (Alba county) & 250 & $220-280$ & Normal amylase activity. \\
\hline 2- Gambas (Alba county) & 220 & $220-280$ & Normal amylase activity \\
\hline 3- Gambas (Alba county) & 217 & $220-280$ & Normal amylase activity. \\
\hline 4- Aiud (Alba county) & 243 & $220-280$ & Normal amylase activity. \\
\hline 5- Ghirbom (Alba county) & 276 & $220-280$ & Normal amylase activity \\
\hline 6- Blaj (Alba county) & 336 & $220-280$ & $\begin{array}{l}\text { Low amylase activity. } \\
\text { Using this flour has resulted in bread that } \\
\text { is not developed, with low volume and } \\
\text { very dry pulp.. Require the addition of } \\
\text { diastatic malt. }\end{array}$ \\
\hline 7- Craciunel (Alba county) & 225 & $220-280$ & Normal amylase activity. \\
\hline $\begin{array}{l}\text { 8- Valea Lunga (Alba } \\
\text { county) }\end{array}$ & 375 & $220-280$ & $\begin{array}{l}\text { Low amylase activity. } \\
\text { Using this flour has resulted in bread that } \\
\text { is not developed, with low volume and } \\
\text { very dry pulp.. Require the addition of } \\
\text { diastatic malt. }\end{array}$ \\
\hline 9- Blaj (Alba county) & 319 & $220-280$ & $\begin{array}{l}\text { Low amylase activity. } \\
\text { Using this flour has resulted in bread that } \\
\text { is not developed, with low volume and } \\
\text { very dry pulp.. Require the addition of } \\
\text { diastatic malt. }\end{array}$ \\
\hline $\begin{array}{l}\text { 10- Valea Lunga (Alba } \\
\text { county) }\end{array}$ & 322 & $220-280$ & $\begin{array}{l}\text { Low amylase activity. } \\
\text { Using this flour has resulted in bread that } \\
\text { is not developed, with low volume and } \\
\text { very dry pulp.. Require the addition of } \\
\text { diastatic malt. }\end{array}$ \\
\hline
\end{tabular}

\section{Conclusions}

Determination of the fall (Falling Number), an empirical test that relies on the ability of endogenous $\alpha$-amylase to reduce viscosity of the suspension treated warm flour is used, large scale milling and bakery industry to predict, assess Baking quality of flour. Falling number - index drop is inversely proportional to $\alpha$--amylase activity of flour and acceptable field depends on cereal product. In the wheat sprouted, with a low number Falling, dextrin formed by $\alpha$-amylase action that result in a core of sticky bread. It was found from experiments that the values fall turnover (FN) does not shrink in direct proportion to the percentage of seeds germinate. Amylolitic activity depends on the stage of sprouting of grain. Lack $\alpha$-amylase activity can be corrected by adding malt grain $\alpha$-amylase or fungal.

\section{References}

1. Amon S. S., Damus K., Si Chin J., 1981. Infant botulism: epydemiology and relation to sudden infant death syndrome. Epidemiol. Rev. 3(1981).

2. Popa M., 2006. Food safety and Security, Book Publishing House of Science, Cluj Napoca. 
3. Popa, M., 2009. Science foundations of goods, Book Publishing House of Science, Cluj Napoca.

4. Savu Ctin., 2008. Hygiene and product control, Semne Publishing, Bucureşti.

5. Tofan C., 2004. Food Microbiology, AGIR Publishing, Bucharest.

6. National food safety best practice guidelines, Uranus Publishing, Bucharest, 2007.

7. SR ISO 7954-2001 General directives for the count of yeasts and moulds. The technique of colnies counting at $25^{\circ} \mathrm{C}$. 